\title{
ALK NM_004304.4:C.3520T>C
}

National Cancer Institute

\section{Source}

National Cancer Institute. ALK NM 004304.4:C.3520T>C. NCI Thesaurus. Code C146866.

A nucleotide substitution at position 3520 of the coding sequence of the ALK gene where thymine has been mutated to cytosine. 